\title{
CAMPUR KODE DALAM PERCAKAPAN DI AKUN FACEBOOK ONLINE SHOP BERBAHASA MINANGKABAU
}

\author{
Tiwi Amelia Agustina ${ }^{1 *}$, Reniwati ${ }^{2}$ Lindawati $^{3}$ \\ tiwiameliaagustina@gmail.com ${ }^{l *}$,reniwati@hum.unand.ac.id ${ }^{2}$,lindawatisaun@hum.unand.ac.id ${ }^{3}$ \\ Universitas Andalas, Padang, Indonesia ${ }^{1,2,3}$
}

\begin{abstract}
ABSTRAK
Artikel ini mendeskripsikan bahasa yang membentuk peristiwa campur kode, mendeskripsikan satuan lingual, dan penyebab terjadinya campur kode pada tuturan penjual dan pembeli online shop dalam akun facebook. Adapun teori yang digunakan dalam penelitian ialah sosiolinguistik, yaitu campur kode, penyebab terjadinya campur kode, peristiwa tutur, komponen tutur, faktor situasional, kedwibahasaan, serta bentuk-bentuk satuan lingual. Metode yang digunakan dalam penelitian ini ialah metode simak dengan teknik dasar sadap, kemudian dilanjutkan dengan teknik lanjutan catat.

Dari analisis data campur kode pada facebook online shop berbahasa Minangkabau ditemukan tiga bahasa yang membentuk peristiwa campur kode, yaitu campur kode bahasa Minangkabau dengan bahasa Indonesia, bahasa Minangkabau dengan bahasa Inggris, dan bahasa Minangkabau dengan bahasa Indonesia dan bahasa Inggris. Satuan lingual pada campur kode terdiri dari: satuan lingual dalam bentuk kata, frasa, klausa, dan kalimat. Faktor yang menyebabkan terjadinya campur kode ialah latar belakang penutur, latar belakang kebahasaan penutur, dan faktor kebutuhan.
\end{abstract}

Kata-kata kunci: Minangkabau; Campur Kode; Online Shop; Facebook

\section{CODE-MIXING DURING CONVERSATION IN FACEBOOK ONLINE SHOP ACCOUNT}

\begin{abstract}
This article describes the language that forms code-mixing events, describes lingual units, and the causes of codemixing in the speech of online shop sellers and buyers in their Facebook account. The method used in this research is the observation method with the basic tapping technique, then proceeding with the advanced note-taking technique. The analysis of code-mixing data on the Minangkabau language Facebook online shop found that three languages formed the code-mixing event, namely mixing the code of the Minangkabau language with Indonesian, the Minangkabau language with English, and the Minangkabau language with Indonesian and English. The lingual units in the code mix consist of lingual units in words, phrases, clauses, and sentences. The factors that cause code-mixing are the speaker's background, the speaker's language background, and the need factor.
\end{abstract}

Keywords: Minangkabau; Code-mixing; Online shop; Facebook 


\section{PENGANTAR}

Online Shop merupakan cara untuk berbelanja melalui internet. Menurut Suherman (2002), jual beli melalui internet adalah sebuah akad jual beli yang dilakukan dengan menggunakan sarana elektronik atau internet, baik berupa barang maupun berupa jasa. Kegiatan ini memiliki banyak keuntungan yang diberikan kepada pelanggan, di antaranya belanja lebih hemat waktu dan tenaga, pelanggan tidak perlu berjalan jauh untuk belanja, dapat melihat harga barang yang ditawarkan, pemesanan barang dapat dilakukan kapan saja dan di mana saja dengan hanya melihat dan menggeser-geser layar hand phone dan pilih mana barang yang diinginkan.

Di antara media sosial yang ada, ternyata yang paling digemari yaitu facebook. Facebook dijadikan sarana untuk mereka yang ingin berdagang. Barang yang dijualbelikan pun beraneka ragam, mulai dari produk pakaian, produk elektronik, produk kecantikan, sampai produk makanan. Dengan berbagai barang yang ditawarkan tersebut, membuat pelanggan lebih mudah untuk membeli apa yang dibutuhkan.

Pada online shop, akan terjadi percakapan antara penjual dan pembeli di kolom komentar akun facebook. Mereka menggunakan berbagai bahasa, salah satu bahasa yang digunakan yaitu bahasa Minangkabau dalam percakapan jual beli. Dalam percakapan tersebut, peneliti menemukan berbagai variasi bahasa yang digunakan seperti, abreviasi, kesalahan berbahasa, dan campur kode.

Menurut Verlin (2018), abreviasi adalah proses penanggalan sebagian atau beberapa bagian leksem yang membentuk kata baru tanpa mengubah arti. Selain abreviasi, juga terdapat kesalahan berbahasa pada percakapan online shop. Menurut Setiawan (2020), pengguna biasanya menuliskan apa yang diinginkan dan mengungkapkan sesuai yang dikehendakinya. Hal itulah yang membuat banyaknya terjadi kesalahan berbahasa pada percakapan facebook online shop. Di samping itu, juga terdapat penggunaan campur kode di dalam tuturan percakapan online shop. Campur kode merupakan percampuran dua bahasa atau lebih

Dari beberapa variasi bahasa yang ditemukan oleh peneliti di facebook online shop, ditemukan bahwa penggunaan campur kode yang dilakukan oleh penjual dan pembeli lebih dominan dari abreviasi dan kesalahan berbahasa. Di samping itu, pengguna campur kode menggunakan bahasa dasar Minangkabau. Oleh karena itu, peneliti akan menjabarkan mengenai campur kode pada tuturan percakapan di facebook online shop.

Menurut Chaer (2010), campur kode merupakan adanya sebuah kode utama atau kode dasar yang digunakan dan memiliki fungsi dan keotonomiannya, sedangkan kode-kode lain yang terlibat dalam peristiwa tutur hanya berupa serpihan-serpihan tanpa fungsi keotonomian sebagai sebuah kode. Pada percakapan sehari-hari terkadang tidak disadari bahwa seringnya pemakaian campur kode berupa sisipan kata, frasa, klausa, dan kalimat yang digunakan dalam komunikasi.

Ketertarikan pada campur kode di media sosial ini dilatarbelakangi oleh maraknya masyarakat Minangkabau baik muda maupun tua bertransaksi jual beli secara online. Peneliti menemukan adanya bahasa Minangkabau yang digunakan terdapat unsur bahasa lain atau terjadi campur kode bahasa dalam tuturan percakapan tersebut. Berdasarkan hasil pengamatan, tuturan online shop secara umum berbahasa Minangkabau. 


\section{KERANGKA TEORI DAN METODE}

Chaer dan Agustina (1995), menjelaskan bahwa campur kode adalah pemakaian dua bahasa atau lebih atau dua varian dari sebuah bahasa dalam satu masyarakat tutur, di mana salah satu merupakan kode utama atau kode dasar yang digunakan yang memiliki fungsi dan keotonomiannya, sedangkan kode-kode lain yang terlibat dalam peristiwa tutur hanya berupa serpihan-serpihan saja, tanpa fungsi atau keotonomian sebagai sebuah kode.

Thelander (dalam Chaer, 2010), mengatakan campur kode terjadi apabila di dalam suatu peristiwa tutur terdapat klausa-klausa atau frasa-frasa yang digunakan terdiri dari klausa dan frasa campuran, dan masing-masing klausa dan frasa tidak lagi mendukung fungsi sendiri-sendiri. Sementara itu, menurut Nababan (1991), bila mana penutur mencampurkan dua atau lebih kode bahasa di dalam satu tuturan itu dinamakan campur kode.

Menurut Suwito (1983), penyebab terjadinya campur kode dapat dikategorikan sebagai berikut.

1. Tipe yang berlatar belakang pada sikap (attitudinal type).

2. Tipe yang berlatar belakang kebahasaan (linguistic type).

Atas dasar latar belakang sikap dan kebahasaan yang saling bergantung dan bertumpang tindih, maka dapat diidentifikasikan beberapa alasan atau penyebab yang mendorong terjadinya campur kode sebagai berikut.

1. Identifikasi peranan. Ukuran yang ditentukan adalah sosial dan pendidikan.

2. Identifikasi ragam. Ditentukan oleh bahasa di mana seorang penutur melakukan campur kode yang akan menempatkan dia dalam tingkat status sosialnya.

3. Keinginan untuk menjelaskan dan menafsirkan. Campur kode juga menandai sikap dan hubungannya terhadap orang lain dan sikap serta hubungan orang lain terhadapnya.

Penyediaan data yang dilakukan pertama dengan melihat akun facebook milik pedagang online shop. Pada postingannya terlihat berbagai komentar dari pembeli di kolom komentar, peneliti akan melihat pencampuran bahasa yang dilakukan penjual dan pembeli online shop di kolom komentar postingan tersebut. Kemudian peneliti akan menyaring apakah percakapan pencampuran bahasa tersebut layak untuk dijadikan data. Data penelitian ini berupa tuturan yang terjadi di akun facebook online shop. Di samping itu, objek penelitian berbentuk satuan lingual yang terdapat campur kode.

Metode dan teknik penyediaan data yang peneliti gunakan ialah metode simak. Dinamakan metode simak karena proses pengerjaannya berupa penyimakan. Peneliti menyimak percakapan penjual dan pembeli di kolom komentar akun facebook online shop. Teknik dasar yang peneliti gunakan yaitu teknik sadap. Peneliti menyadap pembicaraan penjual dan pembeli pada kolom komentar facebook milik penjual online shop. Peneliti memilih datadata yang menggunakan pencampuran bahasa. Jika sudah ditemukan data tersebut, peneliti menyadap percakapan penjual dan pembeli dengan cara memfoto layar pada media sosial dari handphone. Teknik dasar ini dilanjutkan dengan teknik lanjutan. Sesudah melakukan proses penyadapan, peneliti akan mencatat data tersebut. Sudaryanto 
(1993: 133) menamakan teknik tersebut dengan teknik lanjutan catat. Peneliti mencatat semua data yang sudah terkumpul pada kartu data.

Populasi pada penelitian ini ialah seluruh tuturan campur kode pada akun facebook online shop. Sampelnya yaitu tuturan campur kode pada 11 akun facebook online shop yang hanya berteman dengan akun milik peneliti. Peneliti memiliki akun facebook tersebut pada tahun 2015. Akun milik peneliti ini tidak terlibat aktif dalam jual beli, melainkan peneliti hanya menyimak percakapan pada kolom komentar akun facebook online shop. Alasan peneliti mengambil sampel yang demikian, dikarenakan masing-masing akun tersebut menjual barang dagangan yang berbeda, sehingga peneliti mendapatkan data campur kode bervariasi. Maka, 11 akun tersebut dapat mewakili populasi yang ada.

\section{HASIL DAN PEMBAHASAN}

Campur kode yang ditampilkan di sini yaitu (1) bahasa yang membentuk peristiwa campur kode pada tuturan penjual dan pembeli online shop dalam akun facebook, (2) satuan lingual yang membentuk campur kode pada tuturan penjual dan pembeli online shop dalam akun facebook, (3) penyebab terjadinya campur kode pada tuturan penjual dan pembeli online shop dalam akun facebook. Berdasarkan data yang ditemukan dalam percakapan online shop, peneliti menemukan satuan lingual dalam bentuk kata, frasa, dan klausa. Berikut ini disampaikan bentuk-bentuk campur kode tersebut.

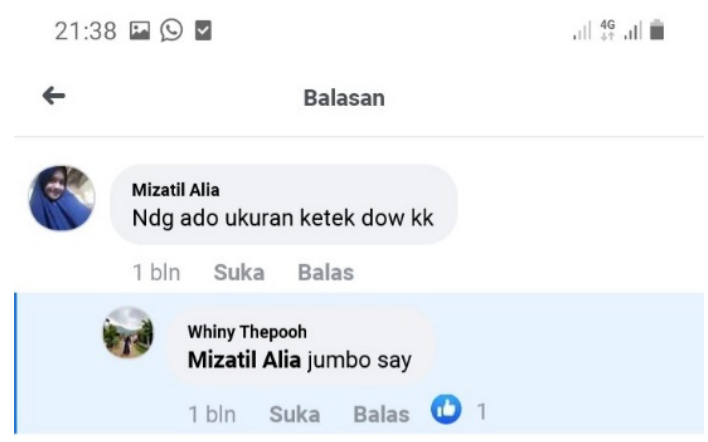

(diambil dari komentar akun Whiny Thepooh, 5 Januari 2020) $\mathrm{Pb}:$ Ndak ado ukuran ketek do, Kak?

Tidak ada ukuran kecil kak 'Apakah ada ukuran kecil, Kak?'

Pj : Mizatil Alia jumbo, Sayang. mizatil alia jumbo sayang '@Mizatil Alia ukuran jumbo, Sayang.’

Pada peristiwa tutur di atas, campur kode yang berupa tataran kata sifat berasal dari bahasa Indonesia yaitu kata jumbo. Kata yang berasal dari bahasa Indonesia itu disisipkan ke dalam bahasa Minangkabau oleh penjual (Pj) yang telah melakukan campur kode antara bahasa Minangkabau dengan bahasa Indonesia, sedangkan pembeli $(\mathrm{Pb})$ 
tidak melakukan pencampuran bahasa. Dalam $K B B I$, kata jumbo berarti 'besar sekali'. Kata jumbo dalam bahasa Minangkabau padanannya yaitu gadang (Saydam, 2004:32).

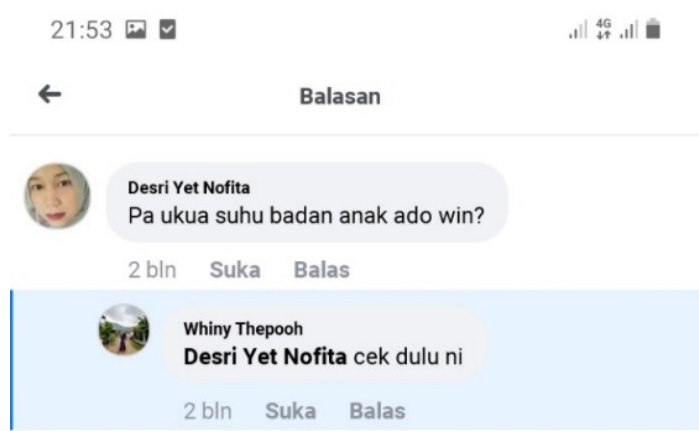

(diambil dari komentar akun Whiny Thepooh, 5 Januari 2020)

$\mathrm{Pb}$ : Paukua suhu badan anak ado, Win?

pengukur suhu badan anak ada win

'Apakah ada termometer untuk anak, Win?'

Pj : Desri Yet Nofita cek dulu, Uni.

desri yet nofita cek dulu uni

‘@Desri Yet Nofita saya cek dulu, Uni.’

Pada peristiwa tutur di atas, campur kode yang berupa tataran kata benda dan kata kerja berasal dari bahasa Indonesia yaitu kata suhu dan cek. Kata yang berasal dari bahasa Indonesia itu disisipkan ke dalam bahasa Minangkabau oleh $\mathrm{Pb}$ dan $\mathrm{Pj}$, sehingga terjadilah campur kode antara bahasa Minangkabau dengan bahasa Indonesia. Bahasa yang dominan digunakan oleh $\mathrm{Pb}$ dan $\mathrm{Pj}$ ialah bahasa Minangkabau. Kata suhu dalam Kamus Besar Bahasa Indonesia, berarti 'ukuran kuantitatif terhadap temperatur; panas dan dingin, diukur dengan termometer'. Kata cek berarti 'periksa'. Padanan masing- masing kata tersebut di dalam bahasa Minangkabau yaitu paneh badan (Saydam, 2004: 286) dan pareso (Saydam, 2004: 46).

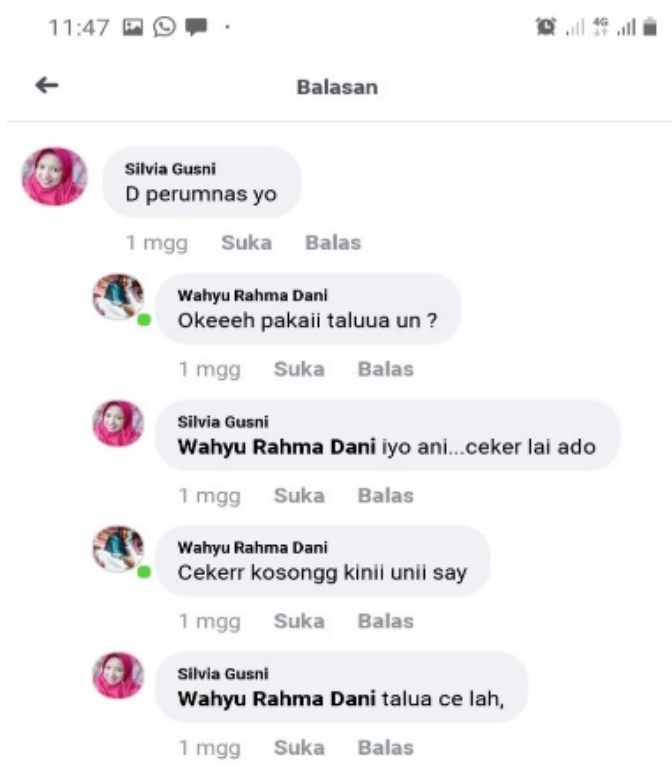


(diambil dari komentar akun Wahyu Rahma Dani, 5 Januari 2020)

$\mathrm{Pb}:$ Di perumnas yo.

Di perumahan nasional ya

'Pesanan diantar ke perumahan nasional, Dani.'

$\mathrm{Pj}:$ Oke. Pakai talua, Uni?

Oke pakai telur uni

'Oke. Apakah pesanan pakai telur, Uni?'

$\mathrm{Pb}$ : Wahyu Rahma Dani iyo, Ani. Ceker lai ado?

wahyu rahma dani iya ani ceker masih ada '@Wahyu Rahma Dani iya. Apakah ceker ada, Ani?’

$\mathrm{Pj}$ : Ceker kosong kini, Uni sayang.

Ceker kosong sekarang uni sayang

'Ceker sekarang tidak ada, Uni sayang.'

$\mathrm{Pb}$ : Wahyu Rahma Dani Talua se lah.

wahyu rahma dani telur saja lah

‘@Wahyu Rahma Dani telur saja kalau begitu, Ani.’

Pada peristiwa tutur di atas, campur kode yang berupa tataran kata benda, kata kerja, dan kata benda berasal dari bahasa Indonesia yaitu perumnas, oke dan ceker. Kata yang berasal dari bahasa Indonesia itu disisipkan ke dalam bahasa Minangkabau oleh $\mathrm{Pb}$ dan $\mathrm{Pj}$, sehingga terjadilah campur kode antara bahasa Minangkabau dengan bahasa Indonesia. Bahasa yang dominan digunakan oleh $\mathrm{Pb}$ dan $\mathrm{Pj}$ ialah bahasa Minangkabau.

Kata perumnas merupakan kontraksi dari perumahan nasional. Dalam Kamus Besar Bahasa Indonesia, kata perumnas berarti 'perumahan dan permukiman yang disediakan oleh pemerintah untuk masyarakat berpenghasilan menengah ke bawah'. Kata oke, berarti 'kata untuk menyatakan setuju; ya', ceker berarti 'kaki dan kuku yang panjang; cakar (pada ayam, elang, dan sebagainya)'. Kata perumnas tidak memiliki padanan dalam bahasa Minangkabau, sedangkan kata oke dan ceker dalam bahasa Minangkabau padanannya yaitu jadih (Saydam, 2004: 146) dan kaki ayam (Saydam, 2004: 337).

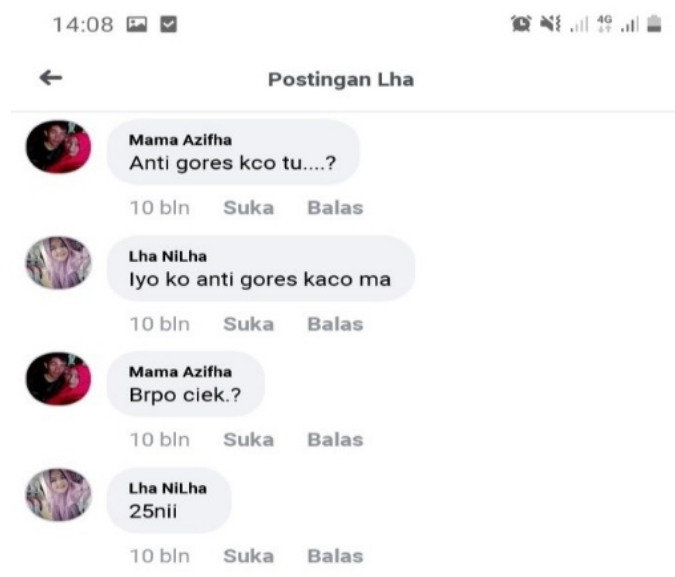

(diambil dari komentar akun Lha Nilha, 10 Januari 2020)

$\mathrm{Pb}:$ Anti gores kaco tu?

Anti gores kaca itu

'Apakah anti gores kaca itu, La?' 
$\mathrm{Pj}$ : Iyo. Iko anti gores kaco ma.

Iya ini anti gores kaca

'Iya. Ini anti gores kaca, Uni.'

$\mathrm{Pb}:$ Barapo ciek?

Berapa satu

'Berapa harganya satu, La?'

$\mathrm{Pj}:$ Rp 25.000, Uni.

Rp 25.000 uni

'Harganya Rp 25.000, Uni.'

Pada peristiwa tutur di atas, campur kode yang berupa tataran frasa berasal dari bahasa Indonesia yaitu frasa anti gores. Frasa anti gores tersebut merupakan frasa eksosentris dalam bahasa Indonesia. Peristiwa tutur 45 ini memperlihatkan bahwa bahasa dominan yang digunakan ialah bahasaMinangkabau. Menurut Kamus Besar Bahasa Indonesia, kata anti berarti 'tidak setuju; tidak suka; tidak senang'. Di samping itu,kata gores berarti 'garis; garit; corek; parut'. Jadi anti gores berarti 'tidak mudah tergaris'. Padanan masing-masing kata tersebut di dalam bahasa Minangkabau yaitu indak suko (Saydam, 2004: 12) dan dituriah (Saydam, 2004: 89). Jadi padanan frasa anti gores dalam bahasa Minangkabau ialah indak dituriah.

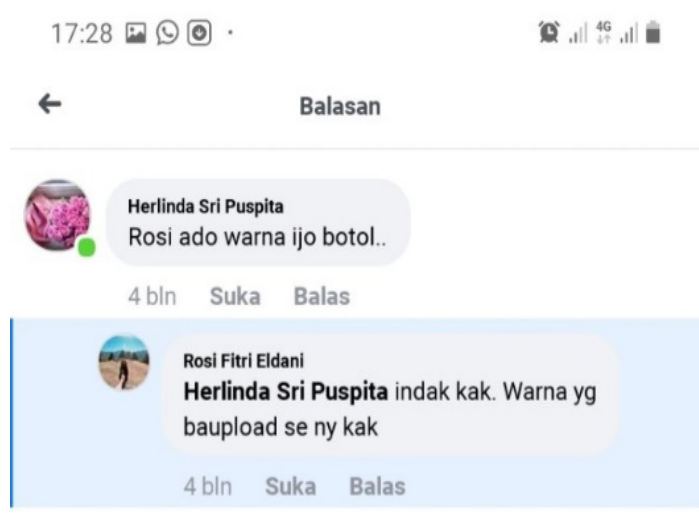

(diambil dari komentar akun Rosi Fitri Eldani, 12 Januari 2020)

$\mathrm{Pb}:$ Rosi, ado warna hijau botol?

Rosi ada warna hijau botol

'Apakah warna hijau botol ada, Rosi?'

$\mathrm{Pj}$ : Indak, Kak. Warna yang baupload se nyo, Kak.

Tidak kak warna yang diunggah saja kak

'Tidak ada, Kak. Warna yang diunggah saja yang ada, Kak.'

Pada peristiwa tutur di atas, campur kode yang berupa tataran frasa berasal dari bahasa Indonesia dan bahasa Inggris yaitu frasa hijau botol dan yang baupload. Frasa tersebut merupakan frasa endosentris dan frasa eksosentris dalam bahasa Indonesia dan bahasa Inggris yang dilakukan oleh $\mathrm{Pb}$ dan $\mathrm{Pj}$. Peristiwa tutur ini memperlihatkan bahwa $\mathrm{Pb}$ dan $\mathrm{Pj}$ melakukan pencampuran bahasa. Menurut Kamus Besar Bahasa Indonesia, kata hijau berarti 'warna yang serupa dengan warna daun pada umumnya'. Kata botol, berarti 'wadah untuk benda cair, yang berleher sempit dan 
biasanya dibuat dari kaca atau plastik'. Jadi hijau botol berarti 'warna daun yang mengarah padawarna botol'. Kata upload, berarti ‘mengunggah'. Padanan masing-masing kata tersebut dalam bahasa Minangkabau yaitu ijau (Saydam, 2004: 98) dan boto (Saydam, 2004: 37). Jadi padanan frasa hijau botol dalam bahasa Minangkabau ialah ijau boto, sedangkan kata upload tidak memiliki padanan dalam bahasa Minangkabau.

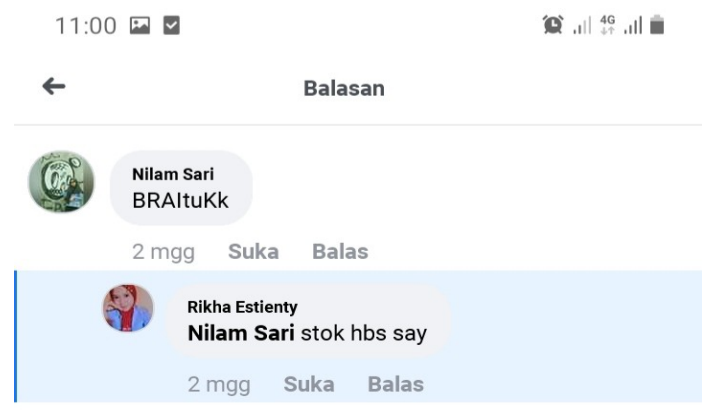

(diambil dari komentar akun Rikha Estianty, 5 Januari 2020)

$\mathrm{Pb}$ : Bara itu, Kak?

Berapa itu kak

'Berapa harganya, Kak?'

$\mathrm{Pj}$ : Nilam Sari Stok habis, Sayang.

Nilam sari stok habis sayang

'@Nilam Sari stok barang habis, Sayang.'

Pada peristiwa tutur di atas, campur kode yang berupa tataran klausa verbal berasal dari bahasa Indonesia yaitu klausa stok habis. Adapun bahasa yang dominan yang dilakukan oleh $\mathrm{Pb}$ dan $\mathrm{Pj}$ yaitu bahasa Minangkabau yang disisipkan bahasa Indonesia. Dalam Kamus Besar Bahasa Indonesia, kata stok berarti 'sediaan barang yang diperdagangkan'. Kata stok dalam bahasa Minangkabau padanannya yaitu barang (Saydam, 2004: 22).

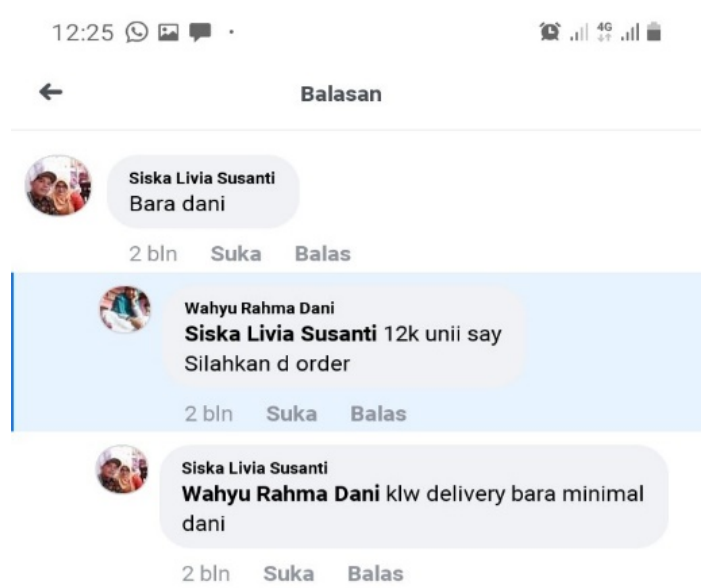

(diambil dari komentar akun Wahyu Rahma Dani, 5 Januari 2020)

$\mathrm{Pb}$ :Bara, Dani?

berapa dani

'Berapa harganya, Dani?'

$\mathrm{Pj}$ : Siska Livia Susanti 12 ribu, Uni sayang. Silakan di order! 
siska livia susanti 12 ribu uni sayang silakan di pesan

‘@Siska Livia Susanti harganya12 ribu. Silakan di pesan, Uni!’

$\mathrm{Pb}$ : Wahyu Rahma Dani kalau delivery bara minimal, Dani?

wahyu rahma dani kalau pengantaran berapa minimal dani

‘@Wahyu Rahma Dani berapa jumlah minimal barang agar bisa diantarkan, Dani?’

Pada peristiwa tutur di atas, campur kode yang berupa tataran kata sifat berasal dari bahasa Indonesia yaitu kata minimal. Kata yang berasal dari bahasa Indonesia itu disisipkan ke dalam bahasa Minangkabau oleh Pb, sehingga terjadilah campur kode antara bahasa Minangkabau dengan bahasa Indonesia. Di samping itu, Pb tidak melakukan pencampuran bahasa berupa tataran kata. Menurut Kamus Besar Bahasa Indonesia, kata minimal berarti 'sedikitdikitnya; sekurang-kurangnya'. Padanan kata minimal dalam bahasa Minangkabau yaitu kurang (Saydam, 2004: 188).

Adapun campur kode berupa tataran kalimat perintah pada peristiwa tutur tersebut berasal dari bahasa Indonesia yaitu kalimat silakan diorder. Kalimat silakan diorder merupakan kalimat persilahkan. Selain ditandai oleh intonasi suruh, kalimat persilahkan ditandai juga oleh penambahan kata silakan yang diletakkan di awal kalimat (Ramlan, 2001: 42). Kata silakan dalam Kamus Besar Bahasa Indonesia, berarti ‘sudilah kiranya (kata perintah yang halus)'.

Faktor terjadinya campur kode dikarenakan oleh latar belakang sikap penutur dan latar belakang kebahasaan penutur (Suwito, 1983: 74). Faktor terjadinya campur kode tersebut sebagai berikut.

\section{Sikap Penutur}

Sikap penutur menentukan terjadinya peristiwa campur kode. Dalam tuturan percakapan yang diteliti terdapat penutur $\mathrm{Pb}$ dan $\mathrm{Pj}$ yang melakukan campur kode pada online shop. Mereka melakukan campur kode bahasa Minangkabau dengan bahasa Indonesia dan bahasa Inggris. Peristiwa campur kode ini disebabkan karena sikap penutur tersebut. Penutur memiliki latar belakang sikap yang tidak ingin ketinggalan zaman, sehingga bahasa Indonesia dan bahasa Inggris yang digunakan pada percakapan di media sosial digunakan saat mereka berada di ruang lingkup masyarakat berbahasa Minangkabau.

Campur kode yang dilakukan oleh $\mathrm{Pb}$ dan $\mathrm{Pj}$ online shop terutama pada kalangan ibu-ibu milenial yang update terhadap teknologi dan informasi, seperti whatsapp, instagram, facebook, dan media sosial lainnya. Mereka menggunakan kata dan istilah kekinian. Penggunaan istilah bahasa Inggris akan memberi kesan kelompok muda yang kekinian. Ibu-ibu yang berjiwa muda memang tidak dapat dilihat, tetapi bisa dilihat dari fotonya dan selera pakaian yang ia jual. Online shop menggunakan alat komunikasi yang canggih menunjukkan mereka orang modern atau kekinian.

\section{Latar Belakang Kebahasaan}

Di samping sikap penutur, latar belakang kebahasaan juga mendukung terjadinya peristiwa campur kode. $\mathrm{Pb}$ dan Pj ialah penutur bahasa Minangkabau. Mereka mencampurkan bahasa Minangkabau dengan bahasa Indonesia dan bahasa Inggris. Dalam peristiwa campur kode yang dilakukan oleh $\mathrm{Pb}$ dan $\mathrm{Pj}$ disebabkan karena latar belakang kebahasaan penutur tersebut. 
Mereka juga pandai berbahasa Indonesia, karena bahasa Minangkabau dan bahasa Indonesia merupakan bahasa yang memiliki hubungan kekerabatan. Apalagi anak muda sekarang banyak yang memiliki kosa kata bahasa Inggris di samping belajar di sekolah dan perguruan tinggi. Bahasa Inggris itu sudah tidak asing bagi mereka, karena dari masa anak-anak mereka sudah biasa mendengar, menyanyikan, dan menonton dengan bahasa Inggris.

\section{Kebutuhan}

Faktor lain yang menyebabkan penutur melakukan campur kode pada jual beli online shop yaitu adanya faktor kebutuhan. Transaksi di media sosial menggunakan istilah-istilah asing, seperti online shop, facebook, order, delivery, dan lain sebagainya. Kebutuhan akan kosa kata ini membuat pelaku jual beli melakukan pencampuran bahasa.

\section{PENUTUP}

Berdasarkan analisis data yang telah dilakukan mengenai campur kode dalam tuturan percakapan di akun facebook online shop berbahasa Minangkabau, maka dapat disimpulkan sebagai berikut.

Bahasa yang memperlihatkan terjadinya peristiwa campur kode terdiri dari tiga model, yaitu: campur kode bahasa Minangkabau dengan bahasa Indonesia, bahasa Minangkabau dengan bahasa Inggris, dan bahasa Minangkabau dengan bahasa Indonesia dan bahasa Inggris. Campur kode dalam tuturan percakapan di akun facebook online shop berbahasa Minangkabau terjadi pada tataran kata, yaitu 61 tuturan; tataran frasa terjadi pada 22 tuturan; tataran klausa terjadi pada 2 tuturan; dan tataran kalimat terjadi pada 2 tuturan.

Faktor yang menyebabkan terjadinya campur kode ialah sikap penutur, di mana penutur merupakan ibu-ibu milenial yang menggunakan kata dan istilah kekinian. Online shop menggunakan alat komunikasi yang canggih, yang menunjukkan mereka orang modern dan kekinian. Penyebab terjadinya campur kode yang kedua ialah latar belakang kebahasaan penutur, di mana penutur yang semula berbahasa Minangkabau juga pandai menggunakan bahasa Indonesia. Selain itu, anak muda sekarang juga banyak yang memiliki kosa kata bahasa Inggris. Bahasa Inggris sudah tidak asing lagi bagi mereka, karena dari masa anak-anak mereka biasa mendengar, menyanyikan, dan menonton dengan bahasa Inggris. Penyebab terjadinya campur kode yang ketiga ialah faktor kebutuhan, di mana transaksi di media sosial menggunakan istilah-istilah asing. Kebutuhan akan ini membuat pelaku jual beli melakukan pencampuran bahasa.

\section{REFERENSI}

Annisa, I Nengah Suandi, dkk. 2017. "Campur Kode dalam Transaksi Jual Beli pada Media Online Shop di Singaraja dan Denpasar". Jurnal Program Studi Pendidikan Bahasa dan Sastra Indonesia Volume: Vol. 4. No. 2. Tahun 2016. Universitas Pendidikan Ganesha. https://ejournal.undiksha.ac.id.

Chaer, Abdul dan L. A. 2010. Sosiolinguistik Perkenalan Awal. Jakarta: Rineka Cipta.

Erawati, Yolani. 2018. "Campur Kode dalam Video Instagram Minang LIPP”. (Skripsi). Padang: Fakultas Ilmu Budaya.

Fitria, Tira Nur. 2017. "Bisnis Jual Beli (Online Shop) dalam Hukum Islam dan Hukum Negara". Jurnal Ilmiah Ekonomi Islam (Vol. 03 No. 01, Maret 2017),. STIE-AAS Surakarta. www.jurnal.stie-aas.ac.id.

Kalangit, Rani Frisilia. 2016. "Alih Kode dalam Instagram (Suatu Analisis Sosiolinguistik)”.Jurnal Elektronik 
Fakultas Sastra Universitas Sam Ratulangi 4 (5), 2016. Manado: Fakultas Ilmu Budaya Universitas Sam Ratulangi. https://ejournal.unsrat.ac.id.

Kridalaksana, Harimutri. 2008. Kamus Linguistik. Jakarta: PT Gramedia Pustaka Utama.

Kridalaksana, Harimutri.2010. Pembentukan Kata dalam Bahasa Indonesia. Jakarta: PT Gramedia Pustaka Utama.

Lindawati. 2015. Bahasa Minangkabau. Padang: Minangkabau Press.

Mahsun. 2005. Metode Penelitian Bahasa : Tahapan Strategi, Metode, dan Tekniknya. Jakarta: PT Rajagrafindo Persada.

Manaf, Ngusman Abdul. 2009. Sintaksis (Teori dan Terapan dalam Bahasa Indonesia). Padang: Sukabina Press.

Nababan. P. W. J. 1991. Sosiolinguistik Suatu Pengantar. Jakarta: Gramedia Pustaka Utama.

Nurhaliza, Siti. 2019. "Studi tentang Perubahan Preferensi Konsumen dalam Belanja Offline ke Online di Kota Semarang". (Skripsi). Semarang: Universitas Diponegoro Fakultas Ekonomi dan Bisnis. https://eprints.undip.ac.id.

Parera, Jos Daniel. 1993. Sintaksis. Jakarta: PT Gramedia Pustaka Utama.

Pateda, Mansoer. 1987. Sosiolinguistik. Bandung: Angkasa.

Ramlan, M. 2001. Sintaksis Ilmu Bahasa Indonesia. Yogyakarta: CV Karyono.

Sari, Nola. 2018. "Alih Kode dan Campur Kode dalam Film 'Tenggelamnya Kapal Van Der Wijck' (Tinjauan Sosiolinguistik). (Skripsi). Padang: Fakultas Ilmu Budaya.

Saydam, Gouzali. 2004. Kamus Lengkap Bahasa Minangkabau. Padang: Pusat Pengkajian Islam dan Minangkabau (PPIM).

Setiawan, Kodrat Eko Putra. 2020. "Analisis Kesalahan Berbahasa Indonesia pada Status dan komentar di Facebook". Jurnal Bahasa, Sastra, dan Pengajarannya (Vol. 1, No. 1, Juni 2020). Surakarta: IAIN Surakarta. https://ejournal.iainsurakarta.ac.id.

Sudaryanto. 1993. Metode dan Aneka Teknik Analisis Bahasa. Yogyakarta: Duta Wacana University Press.

Suwito.1983. Pengantar Awal Sosiolinguistik Teori dan Problema. Surakarta: Universitas Sebelas Maret.

Syah, Nurul Hasanah. 2017. "Analisis Faktor-Faktor yang Mempengaruhi Keputusan Pembelian melalui online shop di kota Medan”. Jurnal Pascasarjana UIN Sumatera Utara, 2017. Universitas Islam Negeri Sumatera Utara. www.repository.uinsu.ac.id.

Tarigan, Henry Guntur. 2009. Pengajaran Sintaksis. Bandung: Angkasa Bandung.

Tololiju, Amelia Jolinda. 2018. "Campur Kode pada Media Sosial Facebook". Jurnal Elektronik Fakultas Sastra Universitas Sam Ratulangi 3 (3), 2018. Fakultas Ilmu Budaya Universitas Sam Ratulangi. https://ejournal.unsrat.ac.id.

Verlin, Sri dkk. 2018. "Abreviasi dalam Media Sosial Instagram". Jurnal Ilmu Budaya (Vol. 6, No. 2, Desember 2018). Makassar: Universitas Hasanuddin. https://ejournal.unhas.ac.id.

Https://journal.sociolla.com, diakses pada 8 Februari 2020 pukul 00:21 WIB.

Https:/tekno.tempo.co, diakses pada 8 Februari 2020 pukul 23:40 WIB. Https://www.google.com/amp/s//amp/kompas.com/tekno/read/2019/02/05/110800

97/facebook-jadi-medsos-paling-digemari-di-indonesia, diakses September 2019 pukul 11:44 WIB.

Kamus Besar Bahasa Indonesia https://kbbi.web.id. 